\title{
intuitio
}

\section{BREVES LINHAS SOBRE A MUDANÇA CONCEITUAL DA ESFERA PÚBLICA EM HABERMAS}

\author{
BRIEF LINES ON THE CONCEPTUAL CHANGE OF THE \\ PUBLIC SPHERE IN HABERMAS
}

Ricardo Luis Reiter ${ }^{1}$

Resumo: a proposta do presente artigo é apresentar as críticas de Nancy Fraser ao conceito habermasiano de esfera pública. A republicação de Strukturwandel der Öffentlichkeit, ocorrida em 1990 traz uma longa nota onde Habermas reconhece as carências de sua formulação do conceito "esfera pública", tal qual elaborado na primeira edição da referida obra, frente as críticas recebidas por autores e autoras como Fraser. Portanto, o presente artigo apresentará os quatro pontos centrais da crítica de Fraser e apontará desafios futuros a própria Teoria Crítica à luz da reformulação e atualização do conceito "esfera pública" em um cenário onde o sistema político já pode mais ser explicado por um modelo burguês de esfera pública, que é excludente e predominantemente ocupado por uma pequena parcela da população.

Palavras chaves: esfera pública. Habermas. Fraser. democracia

Abstract: the purpose of this article is to present Nancy Fraser's criticism of the Habermasian concept of the public sphere. The republication of Strukturwandel der Öffentlichkeit, which occurred in 1990, brings a long note where Habermas recognizes the shortcomings of his formulation of the concept "public sphere", as elaborated in the first edition of the referred work, in view of the criticism received by authors such as Fraser. Therefore, this article will present the four central points of Fraser's critique

\footnotetext{
1 Pontifícia Universidade Católica do Rio Grande do Sul (PUCRS). http://orcid.org/oooo-00021072-6820. E-Mail: kadoreiter@gmail.com.
} 
and will point out future challenges to the Critical Theory itself in light of the reformulation and updating of the concept of "public sphere" in a scenario where the political system can already be further explained by a bourgeois model of the public sphere, which is exclusive and predominantly occupied by a small portion of the population.

Keywords: public sphere. Habermas. Fraser. Democracy.

\section{INTRODUÇÃO}

O conceito "esfera pública" é central na obra de Habermas. Ele aparece praticamente em todas as principais obras do filósofo alemão e é certamente um conceito chave dentro da teoria do agir comunicativo. Contudo, o significado de esfera pública sofreu uma série de mudanças com o passar dos anos. Mudanças essas que são reflexo do próprio amadurecimento da teoria do agir comunicativo desenvolvido por Habermas.

A partir da publicação da obra Faktizität und Geltung², o poder comunicativo passa a ser visto como "o "poder" que resulta do procedimento deliberativo de discussão e deliberação, que toma forma na esfera pública e que geralmente é contraposto à esfera do poder político-administrativo"3. Assim, a esfera pública faz frente ao subsistema político-administrativo. Há em Habermas esse conflito de dois (sub)sistemas (político-administrativo e econômico) que constantemente avançam sobre o mundo de vida, que é o palco da atuação política do sujeito.

Contudo, como o próprio Habermas reconhece, o conceito de esfera pública, conforme apresentado na obra Strukturwandel der Öffentlichkeit ${ }^{4}$, acabou não sendo suficiente para sustentar a sua teoria política. Tendo em vista a publicação de uma nova edição da obra supracitada em 1990

\footnotetext{
2 A referida obra foi traduzida no Brasil em dois volumes, sob o título Direito e Democracia: entre facticidade e validade, pela editora Tempo Brasileiro.

3 LUBENOW, Jorge Adriano. Esfera pública e democracia deliberativa em Habermas: modelo teórico e discursos críticos. Kriterion, Belo Horizonte, $n^{\circ}$ 121, Jun/2010, p. 240.

4 A referida obra foi traduzida no Brasil sob o título Mudança estrutural da esfera pública, pela Editora Unesp.
} 
- na Alemanha -, Habermas acrescenta um novo prefácio no qual reconhece algumas lacunas na formulação do conceito "esfera pública”. A mais relevante, para este artigo, é a supervalorização que ele dá à esfera pública burguesa, em detrimento as demais esferas públicas, como bem aponta Fraser:

o problema não é apenas que Habermas idealiza a esfera pública liberal, mas também que ele falha em examinar outras esferas públicas, não liberais, não-burguesas e concorrentes. Ou melhor, é precisamente porque ele falha em examinar essas outras esferas públicas que ele acaba idealizando a esfera pública liberal. ${ }^{5}$

Essa questão é central porque até o prefácio da nova edição de Strukturwandel der Öffentlichkeit, Habermas pouco faz referências a "esferas públicas" - no plural. É justamente a partir dos anos 1990, com a publicação de Faktizität und Geltung que o autor passa a tratar de uma pluralidade de esferas públicas que cumprem seu papel de influenciar "as opiniões públicas sobre o sistema político"6.

Portanto, o presente artigo apresenta as críticas de Nancy Fraser ao conceito habermasiano de esfera pública, apresentando inclusive alguns desafios da teoria crítica frente ao conceito. A questão central que Fraser aponta é o déficit de inclusão dos públicos não representados nas esferas públicas e, a partir de quatro críticas pontuais - que serão desenvolvidas no presente artigo - provoca a reatualização do conceito de esfera pública habermasiano, que já não consegue mais responder aos problemas dos modelos democráticos contemporâneos.

\footnotetext{
5 FRASER, Nacy. Rethinking the Public Sphere in CALHOUN, Craig J. Habermas and the Public Sphere. 1992, p. 115. Tradução direta do inglês: "the problem is not only that Habermas idealizes the liberal public sphere but also that he fails to examine other, nonliberal, nonbourgeois, competing public spheres. Or rather, it is precisely because he fails to examine these other public spheres that he ends up idealizing the liberal public sphere".
}

6 HABERMAS, Jürgen. Direito e democracia: entre facticidade e validade, vol. II, p. 95. 


\section{FRASER}

Ao analisar-se o conceito "esfera pública" e, principalmente, como o concebe Habermas, dois artigos aparecem na bibliografia como sendo essenciais. Tratam-se dos artigos Rethinking the public sphere, escrito por Fraser, e Habermas, the public sphere, and democracy: a critical intervention, escrito por Kellner. Ambos os artigos retomam a construção habermasiana do conceito de esfera pública e traçam críticas que, em diversos pontos, convergem. Ambos autores reconhecem a importância que a obra Strukturwandel der Öffentlichkeit possui, principalmente no que diz respeito ao campo das ciências sociais.

Kellner enaltece o trabalho do filósofo alemão, colocando a obra supracitada como uma das mais importantes e relevantes do século XX:

A Transformação Estrutural da Esfera Pública de Jurgen Habermas é um livro imensamente rico e influente que teve grande impacto numa variedade de disciplinas. Também recebeu críticas detalhadas e promoveu discussões extremamente produtivas sobre democracia liberal, sociedade civil, vida pública e mudanças sociais no século XX, entre outras questões. Poucos livros da segunda metade do século $X X$ foram tão seriamente discutidos em tantos campos diferentes e continuam, quase quarenta anos após sua publicação inicial em 1962, a gerar tal controvérsia e percepção produtiva.?

Fraser por sua vez ressalta que a formulação do conceito "esfera pública" por Habermas possibilitou avanços significativos nas teorias de

\footnotetext{
7 KELLNER, Douglas. Habermas, the public sphere, and democracy: a critical intervention. Tradução direta da passagem: “Jurgen Habermas's The Structural Transformation of the Public Sphere is an immensely rich and influential book that has had major impact in a variety of disciplines. It has also received detailed critique and promoted extremely productive discussions of liberal democracy, civil society, public life, and social changes in the twentieth century, among other issues. Few books of the second half of the twentieth century have been so seriously discussed in so many different fields and continue, almost forty years after its initial publication in 1962, to generate such productive controversy and insight".
} 
democracia em sociedades de capitalismo tardio. Habermas forneceu um conceito importante que permitiu contornar uma série de questões pertinentes a movimentos sociais. Por um lado, tal conceito supera lapsos significativos na teoria marxista e socialista, segundo Fraser, que comprometeram a própria concepção de uma democracia socialista, uma vez que as formas de governo socialistas não foram democráticas e participativas, mas sim autoritárias e estatistas. Por outro lado, movimentos como o feminismo também se beneficiam com a definição habermasiana de esfera pública, uma vez que na tradição do feminismo contemporâneo volta e meia usa-se "esfera pública" para referir-se a tudo que está fora da esfera familiar. Para Fraser, usar o conceito de "esfera pública" apenas para referir-se aquilo que não é privado é por demais simplório e mais prejudica do que beneficia os movimentos sociais, como o feminismo, por exemplo.

A idéia de "a esfera pública" no sentido de Habermas é um recurso conceitual que pode ajudar a superar tais problemas. Designa um teatro nas sociedades modernas em que a participação política é decretada por meio da palavra. É o espaço em que os cidadãos deliberam sobre seus assuntos comuns e, portanto, uma arena institucionalizada de interação discursiva. Esta arena é conceptualmente distinta do Estado; é um local para a produção e circulação de discursos que, em princípio, podem ser críticos do Estado. A esfera pública, no sentido de Habermas, é também conceptualmente distinta da economia oficial; não é uma arena de relações de mercado, mas sim uma arena de relações discursivas, um teatro para debater e deliberar em vez de comprar e vender. Assim, este conceito de esfera pública permite-nos manter em vista as distinções entre aparelhos estatais, mercados económicos e associações democráticas, distinções que são essenciais à teoria democrática. ${ }^{8}$

8 FRASER, Nacy. Rethinking the Public Sphere in CALHOUN, Craig J. Habermas and the Public Sphere. 1992, p. 110-111. Tradução direta da passagem: "The idea of "the public sphere" in Habermas's sense is a conceptual resource that can help overcome such problems. It designates 
Contudo, mesmo diante de tais elogios e do reconhecimento da importância do trabalho de Habermas, não se deve ignorar as falhas apresentadas na obra Strukturwandel der Öffentlichkeit. Habermas descreve uma esfera pública que é, em grande medida utópica. As características que ele ressalta como sendo determinantes na esfera pública burguesa praticamente não se aplicavam a ela, salvo raros casos. $O$ resgate do conceito foi extremamente importante, como já salientado. Entretanto, no final da obra permanece um ar saudoso de uma esfera pública por demais idealizada. A obra é finalizada sem indicar uma superação da esfera pública burguesa; ao contrário, permanece um sentimento nostálgico em relação a mesma.

Habermas apresenta como característica central da esfera pública burguesa a participação universal dos cidadãos. A citada esfera pública, na concepção habermasiana - conforme apresentada em Strukturwandel der Öffentlichkeit - é um espaço no qual faz-se necessário igualdade de status. Nela, os participantes falam de igual para igual, sem distinções, como nos casos dos salões e cafés:

$\mathrm{Na}$ França, os salões formavam um enclave peculiar. Enquanto a burguesia, embora quase excluída da direção do Estado e da Igreja, assumia cada vez mais as posições-chave na economia, e a aristocracia compensava essa superioridade material da burguesia com privilégios reais e uma ênfase mais rigorosa da hierarquia no trato social, a nobreza e (assimilada a ela) a alta burguesia bancária e burocrática encontravam-se nos salões em pé de igualdade, por assim dizer, com a intelectua-

\footnotetext{
a theater in modern societies in which political participation is enacted through the medium of talk. It is the space in which citizens deliberate about their common affairs, and hence an institutionalized arena of discursive interaction. This arena is conceptually distinct from the state; it is a site for the production and circulation of discourses that can in principlebe critical of the state. The public sphere in Habermas's sense is also conceptually distinct from the official economy; it is not an arena of market relations but rather one of discursive relations, a theater for debating and deliberating rather than for buying and selling. Thus this concept of the public sphere permits us to keep in view the distinctions among state apparatuses, economic markets, and democratic associations, distinctions that are essential to democratic theory".
} 
lidade. (...) Nos salões das damas do mundo, tanto burgueses quanto aristocratas, circulavam filhos de príncipes e condes, relojoeiros e merceeiros. No salão, o espírito não presta mais serviços ao mecenas. A “opinião" se emancipa das amarras da dependência econômica. ${ }^{9}$

A leitura do processo histórico da formação de uma esfera pública burguesa, nos moldes apresentados por Habermas, é questionada por Fraser. Com base em pesquisas históricas - principalmente a partir de uma abordagem revisionista -, ela aponta que a ascensão da esfera pública burguesa se dá na medida que ela exclui as demais esferas públicas, sendo um dos principais fatores de exclusão o gênero. Portanto, o ideal apresentado por Habermas, de uma esfera pública que permitisse que todos participassem como iguais, está longe da realidade:

Em geral, esta historiografia revisionista sugere uma visão muito mais escura da esfera pública burguesa do que a que emerge do estudo de Habermas. As exclusões e os conflitos que surgiram como adornos acidentais a partir de sua perspectiva tornam-se constitutivos na visão dos revisionistas. O resultado é uma mudança gestual que altera o próprio significado da esfera pública. Já não podemos assumir que a concepção burguesa da esfera pública era simplesmente um ideal utópico não realizado; era também uma noção ideológica masculinista que funcionava para legitimar uma forma emergente de regra de classe. (...) a esfera pública oficial burguesa é o veículo institucional para uma grande transformação histórica na natureza da dominação política. Esta é a mudança de um modo repressivo de dominação para um hegemônico, de uma regra baseada principalmente na aquiescência para uma força superior para uma regra baseada principalmente no consentimento complementado com alguma medida de

9 Habermas, Jürgen. Mudança estrutural da esfera pública. Rio de Janeiro: Unesp, 2014. p. 146. 
repressão. O ponto importante é que este novo modo de dominação política, tal como o mais antigo, assegura a capacidade de um estrato da sociedade para governar o resto. A esfera pública oficial, então, foi, e de fato é, o principal local institucional para a construção do consentimento que define o novo modo hegemônico de dominação". ${ }^{10}$

Contudo, a leitura revisionista não satisfaz a autora. Não se pode simplesmente negar a importância que a formulação habermasiana do conceito esfera pública assumiu nas ciências sociais e teorias políticas contemporâneas, refutando a mesma com base apenas em abordagem histórica. Fraser opta, dessa forma, por apresentar quatro pressupostos adotados por Habermas como sendo centrais à esfera pública burguesa e que não se sustentam quando confrontados com a historiografia revisionista. Portanto, não se trata de anular a formulação habermasiana, mas sim de apontar deficiências históricas da mesma. E nesse quesito, Fraser aponta quatro pressupostos problemáticos na concepção habermasiana da esfera pública: a) a esfera pública deve ser aberta; b) uma única esfera pública é melhor que várias; c) a esfera pública burguesa deve ser uma área discursiva na qual pessoas privadas deliberam sobre assuntos públicos; e d) uma esfera pública democrática que funcione requer uma nítida separação entre sociedade civil e Estado.

10 FRASER, Nacy. Rethinking the Public Sphere in CALHOUN, Craig J. Habermas and the Public Sphere. 1992, p. 116-117. Tradução direta da passagem: "In general, this revisionist historiography suggests a much darker view of the bourgeois public sphere than the one that emerges from Habermas's study. The exclusions and conflicts that appeared as accidental trappings from his perspective become constitutive in the revisionists' view. The result is a gestalt switch that alters the very meaning of the public sphere. We can no longer assume that the bourgeois conception of the public sphere was simply an unrealized Utopian ideal; it was also a masculinist ideological notion that functioned to legitimate an emergent form of class rule. (...) the official bourgeois public sphere is the institutional vehicle for a major historical transformation in the nature of political domination. This is the shift from a repressive mode of domination to a hegemonic one, from rule based primarily on acquiescence to superior force to rule based primarily on consent supplemented with some measure of repression. The important point is that this new mode of political domination, like the older one, secures the ability of one stratum of society to rule the rest. The official public sphere, then, was, and indeed is, the prime institutional site for the construction of the consent that defines the new, hegemonic mode of domination". 
a) o pressuposto que a esfera pública deve ser um espaço aberto a todos os públicos é pressupor que as pessoas possam participar como se fossem iguais. Segundo Fraser, isso não foi realizado na esfera pública burguesa. A historiografia apresenta, conforme constata Fraser, que diversos grupos foram excluídos. Além do mais, as desigualdades de status também não foram superadas, uma vez que

Esta esfera pública seria uma arena em que os interlocutores deixariam de lado características como as diferenças no nascimento e na fortuna e falariam uns com os outros como se fossem pares sociais e econômicos. A frase operativa aqui é "como se". De facto, as desigualdades sociais entre os interlocutores não foram eliminadas, mas apenas mantidas entre parênteses."1

Fraser ressalta que, no modelo burguês de esfera pública, não ocorria a participação efetiva dos participantes. Os ritos e protocolos da esfera pública serviam como mecanismo para evidenciar as desigualdades de status. Com isso, o próprio funcionamento da esfera pública burguesa marginalizava mulheres e plebeus, impedindo-os de participarem como iguais.

Ademais, mesmo supondo que possa haver uma esfera pública onde todos participem como pares, é fato que mulheres costumam ser mais interrompidas que homens, e que elas têm suas falas menosprezadas. Dessa forma, segundo Fraser, a deliberação por diversas vezes serve como máscara para a dominação.

Outro problema da esfera pública burguesa refere-se à bagagem cultural dos participantes. Ela se apresenta como espaço de cultura zero, à medida em que os participantes devem agir como se fossem

\footnotetext{
1 FRASER, Nacy. Rethinking the Public Sphere in CALHOUN, Craig J. Habermas and the Public Sphere. 1992, p. 118-119. Tradução direta da passagem: "This public sphere was to be an arena in which interlocutors would set aside such characteristics as differences in birth and fortune and speak to one another as if they were social and economic peers. The operative phrase here is "as if." In fact, the social inequalities among the interlocutors were not eliminated but only bracketed".
} 
iguais. Contudo, isso na prática é inviável. Em sociedades estratificadas, as diferentes camadas têm diferentes tipos de culturas próprias. Dessa forma, os discursos ou a participação de cidadãos de diferentes estratos sociais dentro de uma arena deliberativa sempre se dará a partir da sua bagagem cultural. E é fato reconhecido que certas manifestações culturais são mais valorizadas ou mais bem quistas que outras. Dessa forma, supor que haverá paridade cultural entre os participantes de uma esfera pública que abarque todas as camadas sociais é uma ilusão.

Tenho argumentado que a concepção burguesa da esfera pública é inadequada na medida em que supõe que a igualdade social não é uma condição necessária para a paridade participativa nas esferas públicas. $O$ que resulta disso para a crítica da democracia realmente existente? Uma tarefa para a teoria crítica é tornar visíveis as formas pelas quais a desigualdade social infecta as esferas públicas formalmente inclusivas existentes e mancha a interação discursiva dentro delas. ${ }^{2}$

b) O conceito de esfera pública, desenvolvido por Habermas, pressupõe que uma única esfera pública é melhor do que várias.

Nas palavras de Fraser,

Permitam-me que comece por recordar que o relato de Habermas sublinha a singularidade da concepção burguesa da esfera pública, a sua pretensão de ser a arena pública, no singular. Além disso, a sua narrativa tende, a este respeito, a ser fiel a essa concepção, uma vez que lança a emergência de públicos adicionais como um desenvolvimento tardio, sinalizando fragmentação e declínio. Esta narrativa, portanto,

\footnotetext{
12 FRASER, Nacy. Rethinking the Public Sphere in CALHOUN, Craig J. Habermas and the Public Sphere. 1992, p. 121. Tradução direta da passagem: "I have been arguing that the bourgeois conception of thepublic sphere is inadequate insofar as it supposes that socialequality is not a necessary condition for participatory parity in public spheres. What follows from this for the critique of actually existing democracy? One task for critical theory is to render visible the ways in which societal inequality infects formally inclusive existing public spheres and taints discursive interaction within them".
} 
tal como a própria concepção burguesa, é informada por um pressuposto avaliativo subjacente, nomeadamente, que o confinamento institucional da vida pública a uma única e abrangente esfera pública é um estado de coisas positivo e desejável, enquanto a proliferação de uma multiplicidade de públicos representa um afastamento, e não um avanço em direção à democracia. ${ }^{13}$

Em sociedades estratificadas, onde apenas haja uma esfera pública, grupos subalternos encontrarão dificuldades para discutir suas necessidades e demandas sociais. Além do mais, quem ocupou historicamente a esfera pública burguesa foram as classes dominantes e não as subalternas. Dessa forma, defende Fraser, a criação de públicos alternativos surge como possibilidade e contestação da legitimidade das pautas e agendas da esfera pública totalizante.

A questão é que, nas sociedades estratificadas, as contrapúblicas subalternas têm um carácter dual. Por um lado, funcionam como espaços de retirada e de reagrupamento; por outro lado, funcionam também como bases e campos de treino para actividades agitacionais dirigidas a públicos mais vastos. É precisamente na dialéctica entre estas duas funções que reside o seu potencial emancipatório. Esta dialéctica permite às contrapúblicas subalternas compensar parcialmente, embora não totalmente, os privilégios participativos injustos

\footnotetext{
13 FRASER, Nacy. Rethinking the Public Sphere in CALHOUN, Craig J. Habermas and the Public Sphere. 1992, p. 122. Tradução direta da passagem: "Let me begin by recalling that Habermas's account stresses the singularity of the bourgeois conception of the public sphere, its claim to be the public arena, in the singular. In addition, his narrative tends in this respect to be faithful to that conception, since it casts the emergence of additional publics as a late development signaling fragmentation and decline. This narrative, then, like the bourgeois conception itself, is informed by an underlying evaluative assumption, namely, that the institutional confinement of public life to a single, overarching public sphere is a positive and desirable state of affairs, whereas the proliferation of a multiplicity of publics represents a departure from, rather than an advance toward, democracy".
} 
de que gozam os membros de grupos sociais dominantes em sociedades estratificadas. ${ }^{14}$

Conforme Fraser aponta, em sociedades estratificadas a presença de múltiplos públicos permite que se realizem arranjos para que todos os grupos sociais possam participar dos debates políticos e possam ser ouvidos. Por mais que haja o risco de que o choque entre os diversos públicos resulte em contestações ao invés de deliberações, a presença de multipúblicos que participem de um ambiente estruturado permite também que competições e negociações culturais e ideológicas venha a ocorrer, dando assim, voz tanto ao grupo dominante quanto aos diversos grupos subalternos.

Já se tratando de sociedades igualitárias e multiculturais, a questão se apresenta de outra forma. Ao se partir do pressuposto - e este é o pressuposto de Fraser - de que participação significa ser capaz de falar com a própria voz e, assim, ao mesmo tempo, construir e expressar a identidade cultural por meio do idioma ${ }^{15}$, então deve-se pensar em um ou mais espaços que permitam que os cidadãos participem como iguais. Entretanto, ao refutar o pressuposto anterior, Fraser defende que nenhuma esfera pública é um espaço de cultura de grau zero. Ou seja, toda esfera pública é resultado da bagagem cultural de seus participantes. Portanto, para que todos possam participar da vida política social, faz-se necessário que haja esferas públicas distintas.

Em geral, então, podemos concluir que a ideia de uma sociedade igualitária e multicultural só faz sentido se supomos uma

14 FRASER, Nacy. Rethinking the Public Sphere in CALHOUN, Craig J. Habermas and the Public Sphere. 1992, p. 124. Tradução direta da passagem: "The point is that in stratified societies, subaltern counterpublics have a dual character. On the one hand, they function as spaces of withdrawal and regroupment; on the other hand, they also function as bases and training grounds for agitational activities directed toward wider publics. It is precisely in the dialectic between these two functions that their emancipatory potential resides. This dialectic enables subaltern counterpublics partially to offset, although not wholly to eradicate, the unjust participatory privileges enjoyed by members of dominant social groups in stratified societies".

is Ver FRASER, Nacy. Rethinking the Public Sphere in CALHOUN, Craig J. Habermas and the Public Sphere. 1992, p. 125. 
pluralidade de arenas públicas nas quais participam grupos com valores e retóricas diversos. Por definição, tal sociedade deve conter uma multiplicidade de públicos. ${ }^{16}$

Fraser termina sua exposição a esse segundo pressuposto, levantando o questionamento sobre a necessidade de levar em consideração a interação contestatória de diferentes públicos e identificar os mecanismos que tornam alguns públicos subordinados a outros.

c) O conceito de esfera pública, desenvolvido por Habermas, pressupõe uma esfera pública burguesa na qual pessoas privadas deliberavam sobre assuntos públicos.

Esse pressuposto é problemático. Existem diversos significados que podem ser atribuídos ao termo público. Fraser discorre alguns parágrafos diferenciando os vários significados, para tratar como público aquilo que pertence a um bem comum ou interesse comum ${ }^{17}$, que, segundo a filósofa, é o significado empregado por Habermas.

O problema dessa concepção se dá na pressuposição de que a deliberação da esfera pública deve ser a deliberação sobre o bem comum. $E$ para isso, abandonam-se demandas pessoais ou de grupos subalternos em prol de demandas que se referem ao "todo".

Em geral, não há maneira de saber antecipadamente se o resultado de um processo deliberativo será a descoberta de um bem comum em que os conflitos de interesse evaporam como meramente aparentes ou a descoberta de que os conflitos de interesse são reais e o bem comum é quimérico. Mas se a existência de um bem comum não pode ser presumida

\footnotetext{
16 FRASER, Nacy. Rethinking the Public Sphere in CALHOUN, Craig J. Habermas and the Public Sphere. 1992, p. 126. Tradução direta da passagem: "I n general, then, we can conclude that the idea of an egalitarian, multicultural society only makes sense if we suppose a plurality of public arenas in which groups with diverse values and rhetorics participate. By definition, such a society must contain a multiplicity of publics".

17 Ver FRASER, Nacy. Rethinking the Public Sphere in CALHOUN, Craig J. Habermas and the Public Sphere. 1992, p. $128-129$.
} 
de antemão, então não há garantia de colocar quaisquer restrições sobre que tipos de tópicos, interesses e pontos de vista são admissíveis em deliberação. ${ }^{18}$

Como apontado anteriormente, em sociedades democráticas, os grupos dominantes tem maior força argumentativa na esfera pública tradicional. O risco de reduzir debates simplesmente para a procura do bem comum está justamente no fato de a quem diz respeito o "bem comum". Ou ainda, corre-se o risco de cair em uma tirania da maioria ${ }^{19}$, tema amplamente abordado por Stuart Mill e Alexis de Tocqueville ${ }^{20}$.

Ainda há mais dois usos do termo privado que são problemáticos para Fraser. Privado pode referir-se a economia e ainda a relações de subordinação ou esferas da vida doméstica. Em ambos os casos, o uso do termo privado acaba por excluir do debate questões que podem sim interessar ao público, mas restringem-se a esferas não públicas, ou seja, privadas. Corre-se o risco aqui de excluir do debate público questões que tangem a responsabilidade de empresas, por exemplo, uma vez que elas possuem capital e propriedade privada. $\mathrm{O}$ mesmo acontece com a dinâmica familiar: não cabe a opinião pública discutir questões que tangem a vida privada familiar. Não se precisa aqui fazer um complexo exercício mental para concluir-se os perigos dessas duas concepções de privado, uma vez que em ambas as

18 FRASER, Nacy. Rethinking the Public Sphere in CALHOUN, Craig J. Habermas and the Public Sphere. 1992, p. 126. Tradução direta da passagem: "In general, there is no way to know in advance whether the outcome of a deliberative process will be the discovery of a common good in which conflicts of interest evaporate as merely apparent or the discovery that conflicts of interest are real and the common good is chimerical. But if the existence of a common good cannot be presumed in advance, then there is no warrant for putting any strictures on what sorts of topics, interests, and views are admissible in deliberation."

19 Em Tocqueville o cerne da questão da tirania da maioria é tratado no capítulo VII do livro Democracia na América vol. I. Já em Mill, sugere-se a leitura de sua obra Sobre a liberdade.

20 Bobbio escreve um sucinto comentário sobre o temor de Tocqueville e Mill provocado pela negação da liberdade, no capítulo 11 do livro Liberalismo e democracia: "A ameaça que deriva da democracia como forma de governo é para ele [Tocqueville], como de resto para seu amigo John Stuart Mill, a tirania da maioria: o perigo que a democracia corre como progressiva realização do ideal igualitário é o nivelamento, cujo efeito final é o depotismo. São duas formas diversas de tirania, e, portanto, ambas embora de maneira diversa, são a negação da liberdade." [p. 57] 
significações o termo privado é utilizado como uma forma de evitar que a sociedade opine sobre práticas acontecem em uma esfera privada.

Diante disso, Fraser ressalta que cabe a teoria crítica tratar com mais rigor e firmeza os tênues limites entre o público e privado, uma vez que tais denominações são utilizadas frequentemente para excluir ou invalidar uma série de pautas da discussão pública do bem comum.

d) O conceito de esfera pública, desenvolvido por Habermas, pressupõe uma nítida separação entre sociedade civil e Estado.

A separação da esfera pública e Estado, defendida por Habermas, apresenta sérios riscos à efetividade das ações movidas na mesma. Conforme argumenta Fraser, se o papel da esfera pública é apenas deliberar sobre questões de interesse comum, sem ter poder para atuar, ou, em outras palavras, se seu papel é meramente formar opinião sem abranger a tomada de decisões, então o resultado será a criação de públicos fracos.

No entanto, há também uma segunda e mais interessante interpretação da suposição burguesa de que uma separação nítida entre a sociedade civil e o Estado é necessária para uma esfera pública de trabalho, que merece um exame mais amplo. Nesta interpretação, "sociedade civil" significa o nexo de associações não-governamentais ou "secundárias" que não são nem econômicas nem administrativas. Nós podemos melhor apreciar a força da reivindicação que a sociedade civil neste sentido deve ser separada do estado se nós recordarmos a definição de Habermas da esfera pública liberal como um "corpo das pessoas privadas montadas para dar forma a um público. A ênfase aqui em "pessoas privadas" sinaliza (entre outras coisas) que os membros do público burguês não são funcionários do Estado e que sua participação na esfera pública não é realizada em nenhuma capacidade oficial. Assim, seu discurso não se traduz em decisões vinculantes e soberanas que autorizem o uso do poder estatal; pelo contrário, ele se manifesta em "opinião pública", comentário crítico sobre a tomada de decisões autorizadas 
que acontece em outros lugares. A esfera pública, em suma, não é o Estado; é antes o corpo informalmente mobilizado da opinião discursiva não-governamental que pode servir como contrapeso ao Estado. De fato, na concepção burguesa, é precisamente esse caráter extragovernamental da esfera pública que confere uma aura de independência, autonomia e legitimidade à "opinião pública" nela gerada. ${ }^{21}$

Com o surgimento da soberania popular, institui-se dentro do Estado uma esfera pública com força suficiente para tornar discursos em leis. Desta forma, constituem-se, usando a terminologia de Fraser, públicos fortes. A questão, portanto, refere-se agora não mais ao retorno ao modelo burguês de esfera pública. Esse modelo tornou-se obsoleto e ultrapassado diante das novas formas de democracia participativa e representativas. A separação ente Estado e sociedade civil (conforme pressupõe o modelo de esfera pública burguesa) acaba ficando obscura. Em contrapartida, surgem dentro das diversas esferas públicas diferentes graus de força. As esferas parlamentares ou legislativas têm poder para tornar demandas públicas em leis, por exemplo. Cabe ressaltar que Fraser reivindica para o

${ }^{21}$ FRASER, Nacy. Rethinking the Public Sphere in CALHOUN, Craig J. Habermas and the Public Sphere. 1992, p. 133 - 134. Tradução direta da passagem: "However, there is also a second, more interesting interpretation of the bourgeois assumption that a sharp separation of civil society and the state is necessary to a working public sphere, one that warrants more extended examination. In this interpretation, "civil society" means the nexus of nongovernmental or "secondary" associations that are neither economic nor administrative. We can best appreciate the force of the claim that civil society in this sense should be separate from the state if we recall Habermas's definition of the liberal public sphere as a "body of private persons assembled to form a public." The emphasis here on "private persons" signals (among other things) that the members of the bourgeois public are not state officials and that their participation in the public sphere is not undertaken in any official capacity. Accordingly, their discourse does not eventuate in binding, sovereign decisions authorizing the use of state power; on the contrary, it eventuates in "public opinion," critical commentary on authorized decision-making that transpires elsewhere. The public sphere, in short, is not the state; it is rather the informally mobilized body of nongovernmental discursive opinion that can serve as a counterweight to the state. Indeed, in the bourgeois conception, it is precisely this extragovernmental character of the public sphere that confers an aura of independence, autonomy, and legitimacy on the "public opinion" generated in it." 
parlamento o status de "esfera pública", uma vez que Habermas defende o contrário, o parlamento não é uma "esfera pública”.

Os novos modelos de democracia representativa e participativa levantam novas questões, que já não podem mais ser respondidas pelo antigo formato da esfera pública burguesa. Surge o problema da comunicação entre as esferas públicas fracas e fortes. E também a questão da responsabilidade das esferas fortes com as fracas. Fraser parece defender um modelo político híbrido para resolver estas questões. Por híbrido, entende-se sistemas democráticos representativos e diretos, alternando-se em setores diferentes da sociedade. Ela sugere que se repense muitas das estruturas políticas, justamente para fortalecer as esferas públicas fortes, sem deixar de atender as reivindicações das esferas públicas fracas. Para tal, ela defende que em certos níveis, precisarão haver espaços de democracia direta, como por exemplo em empresas de gestão coletiva, creches comunitárias ou comunidades residenciais.

Portanto, um desafio para a teoria crítica atualmente é repensar a relação do sistema democrático e suas relações com a esfera pública:

qualquer concepção da esfera pública que exija uma separação clara entre a sociedade civil (associativa) e o Estado será incapaz de imaginar as formas de autogestão, coordenação interpública e responsabilização política que são essenciais para uma sociedade democrática e igualitária. A concepção burguesa da esfera pública, portanto, não é adequada para a teoria crítica contemporânea. O que é necessário, ao contrário, é uma concepção pós-burguesa que nos permita visualizar um papel maior para (pelo menos algumas) esferas públicas do que a mera formação de opinião autônoma removida da tomada de decisão autoritária. Uma concepção pós-burguesa nos permitiria pensar sobre públicos fortes e fracos, bem como sobre várias formas híbridas. Além disso, isso nos permitiria teorizar a gama de relações possíveis entre tais públicos, o que ampliaria nossa capacidade de vislumbrar 
possibilidades democráticas além dos limites da democracia realmente existente. ${ }^{22}$

\section{O QUE FAZER?}

As críticas traçadas pela teoria crítica ao conceito habermasiano de esfera pública parecem, em um primeiro momento, colocar em xeque se este conceito ainda possui validade dentro das teorias sociais e políticas contemporâneas. Destacam-se aqui as críticas apontadas pelas feministas e que são reunidas por Benhabib no artigo Sobre um modelo deliberativo de legitimidade democrática ${ }^{23}$.

Não se trata necessariamente de abandonar o conceito de esfera pública, mas sim de sua atualização. O que é reivindicado pela teoria crítica, em sua assim chamada atual geração, não é uma esfera pública absoluta, excludente e centralizada na figura do homem burguês. É preciso cada vez mais integrar os diversos, diferentes e múltiplos públicos aos debates políticos. Como bem apresentado durante o artigo, a preocupação central das críticas de Nancy Fraser é pela participação de todos os públicos. Sobre essa preocupação de Fraser, cabe aqui ressaltar o comentário escrito por Benhabib:

22 FRASER, Nacy. Rethinking the Public Sphere in CALHOUN, Craig J. Habermas and the Public Sphere. 1992, p. 133-134. Tradução direta da passagem: any conception of the public sphere that requires a sharp separation between (associational) civil society and the state will be unable to imagine the forms of self-management, interpublic coordination, and political accountability that are essential to a democratic and egalitarian society. The bourgeois conception of the public sphere, therefore, is not adequate for contemporary critical theory. What is needed, rather, is a postbourgeois conception that can permit us to envision a greater role for (at least some) public spheres than mere autonomous opinion formation removed from authoritative decision making. A postbourgeois conception would enable us to think about strong and weak publics, as well as about various hybrid forms. In addition, it would allow us to theorize the range of possible relations among such publics, which would expand our capacity to envision democratic possibilities beyond the limits of actually existing democracy.

23 Ver WERLE, Edilson Luis; MELO (org.), Rúrion Soares (org.) Democracia deliberativa, 2007, p. $47-79$. 
Desenvolvendo o modelo de uma rede dispersa, heterogênea, de vários públicos, Nancy Fraser tem argumentado sobre como, de fato, podem ser acomodadas as preocupações das mulheres, bem como as de outros grupos excluídos, uma vez que o modelo unitário de esfera pública tenha sido abandonado. Essa rede de públicos não unitária e dispersa pode acomodar os desejos das mulheres por seu próprio espaço, em seus próprios termos. Em tais "contrapúblicos subalternos", para usar o termo de Fraser, as fronteiras entre o público e o privado, por exemplo, podem ser renegociadas, repensadas, contestadas e reformuladas. Todavia, existe um longo caminho entre repensar e transformar social e culturalmente tais distinções, como a relação público e privado, e a sua implementação na legislação e regulação governamental. (...) Os públicos formadores de opinião, tais como, por exemplo, aqueles encontrados nos movimentos sociais, podem levar-nos a reconsiderar e repensar muitas questões controversas sobre a privacidade, a sexualidade e a intimidade; mas isso não significa que a consequência única, ou mesmo a mais desejável, de tais processos de deliberação pública de ser a legislação geral. Portanto, quando concebida como um médium anônimo, plural e múltiplo, de comunicação e deliberação, a esfera pública não precisa homogeneizar e reprimir a diferença. Heterogeneidade, alteridade e diferença podem encontrar expressão em múltiplas associações, redes e fóruns de cidadãos, todos constituindo a vida pública sob o capitalismo tardio. ${ }^{24}$

O conceito "esfera pública", tal qual legado por Habermas, não deve ser abandonado. Cabe agora a teoria crítica retomar, aprofundar e repensar o conceito para pensar e reatualizar a própria teoria da democracia e suas

24 BENHABIB, Seyla. Sobre um modelo deliberativo de legitimidade democrática in WERLE, Edilson Luis; MELO (org.), Rúrion Soares (org.) Democracia deliberativa, 2007, p. 74 - 75. 
variações. Em tempos onde as instituições políticas estão sendo desacreditadas, em grande medida por não atenderem as demandas e pautas das esferas públicas plurais, a proposta de Fraser mostra-se como uma relevante proposta de resgatar a credibilidade nas instituições políticas.

Portanto, a leitura de Fraser sobre o conceito de esfera pública, tal qual cunhado por Habermas, aponta ao menos quatro desafios iniciais à Teoria Crítica. O primeiro refere-se ao desafio da Teoria Crítica em identificar as formas pela qual as desigualdades sociais infectam e interferem nas diversas esferas públicas, as tornando exclusivas. Relacionado ao primeiro desafio, Fraser aponta como segunda pauta da Teria Crítica identificar os motivos que tornam alguns públicos subalternos a outros nos debates. Ou, em outras palavras, é preciso que a Teoria Crítica, como aponta Fraser, assuma para si a discussão sobre a relação de subordinação de diversos públicos.

$\mathrm{O}$ terceiro desafio refere-se à problemática conceitual dos termos público e privado. Mais especificamente, cabe a Teoria Crítica repensar os limites e a relação entre público e privado, para evitar que tais conceitos sejam utilizados para incluir ou excluir participantes dos debates públicos. A quarta questão apontada por Fraser é repensar a própria estrutura ou modelo de democracia, de tal forma que a estrutura política aproxime os diversos públicos dos debates políticos. Portanto, cabe a Teoria Crítica repensar o sistema político como um todo, fundamentando-o na participação de todos os públicos em diversas esferas públicas. Para tal, é importante que as esferas públicas fortes consigam dialogar com as esferas públicas fracas, e que sejam garantidas esferas públicas onde todos os públicos possam participar, sem serem ou sentirem-se constrangidos.

Por fim, as críticas apontadas por Fraser permitem pensar nos novos desafios da Teoria Crítica a luz da reformulação do conteúdo do conceito "esfera pública", cunhado por Habermas. Em tempos de questionamento dos modelos de Democracia, Fraser aponta algumas direções seguras para seguir. 


\section{REFERENCIAS}

BENHABIB, Seyla. Sobre um modelo deliberativo de legitimidade democrática. In: WERLE, Edilson Luis; MELO, Rúrion Soares (org.). Democracia deliberativa. São Paulo: Editora Singular, 2007. p. 74-75.

BOBBIO, Norberto. Liberalismo e democracia. 6. ed. Brasília: Editora Universidade de Brasília, 1994. 97 p.

FRASER, Nacy. Rethinking the Public Sphere. In: CALHOUN, Craig J. Habermas and the Public Sphere. Massachusetts: Massachusetts Institute of Technology, 1992. p. 109-142.

HABERMAS, Jürgen. Direito e democracia: entre facticidade e validade, vol. II. 2. ed. Rio de Janeiro: Tempo Brasileiro, 2011.

KELLNER, Douglas. Habermas, the public sphere, and democracy: a critical intervention. Disponível em: https://pages.gseis.ucla.edu/faculty/kellner/papers/habermas.htm. Acesso em: 21 fev. 2019. https://doi. org/10.1057/9781137373311.0005

LUBENOW, Jorge Adriano. Esfera pública e democracia deliberativa em Habermas: modelo teórico e discursos críticos. Kriterion, Belo Horizonte, $\mathrm{n}$. 121, p. 227-258, jun. 2010. https://doi.org/10.1590/s0100-512×2010000100012 MILL, John Stuart. Sobre a liberdade/ A sujeição das mulheres. Porto Alegre: Editora Schwarcz, 2017. 377 p.

TOCQUEVILLE, Alexis de. A democracia na América: leis e costumes, vol. I. São Paulo: Martins Fontes, 1998.

\section{ENDEREÇO CORRESPONDÊNCIA}

Pontifícia Universidade Católica do Rio Grande do Sul (PUCRS). Av. Ipiranga, 6681 - Partenon, Porto Alegre - RS, 90619-900 